\title{
Correction to: Scrutinising what Open Access Journals Mean for Global Inequalities
}

\author{
Márton Demeter ${ }^{1} \cdot$ Romina Istratii $^{2,3}$
}

(c) Springer Science+Business Media, LLC, part of Springer Nature 2020

\section{Correction to: Publishing Research Quarterly https://doi.org/10.1007/s12109-020-09771-9}

The co-author's first name is misspelled in the published article. The correct name is "Romina" Istratii, and not "Ronina". In addition, the co-author's affiliation should be updated to:

SOAS University of London,

Thornhaugh Street, Russell Square, London, WC1H 0XG,

Russell Square College Buildings,

Room 333.

Publisher's Note Springer Nature remains neutral with regard to jurisdictional claims in published maps and institutional affiliations.

The original article can be found online at https://doi.org/10.1007/s12109-020-09771-9.

Márton Demeter

Demeter.Marton@uni-nke.hu

1 National University of Public Service, Ludovika Square 2, Annex Building (Szárnyépület), Office 223, 1083 Budapest, Hungary

2 SOAS University of London, Flat 5 Aylmer Court, Sheldon Avenue, London N2 0BU, UK

3 SOAS University of London, Thornhaugh Street, Russell Square, Russell Square College Buildings, Room 333, London WC1H 0XG, UK 